\title{
Perbandingan Adverbia Penanda Waktu Bahasa Korea dan Bahasa Indonesia
}

\section{The Comparative Study of Time Adverbs in Korean and Indonesian Languages}

\author{
Jayanti Megasari ${ }^{1}$, Ashanti Widyana ${ }^{2}$ \\ jayanti_megasari@upi.edu ${ }^{1}$ \\ Universitas Pendidikan Indonesia ${ }^{1}$ \\ ashantiwdn@upi.edu ${ }^{2}$ \\ Universitas Pendidikan Indonesia ${ }^{2}$
}

\begin{abstract}
This is a comparative study of Korean and Indonesian language. This study aims to describe the form of time markers adverbs in Korean and Indonesian and also to analyze the differences and similarities of the time markers of Korean and Indonesian language. The simple sentences in Korean are translated into Indonesian by following the Indonesian language rules that apply as objects of analysis. It is found that (1) the adverb form of time marker in Korean and Indonesian has very noticeable differences; (2) the time marker in Korean is adverb but it is not applied in Indonesian language. On the other hand, the time marker in Indonesian is adverb but in Korean, it is only suffix particles.
\end{abstract}

Keywords: adverbs, Indonesian language, Korean language, language comparison, time markers

\section{INTISARI}

Penelitian ini adalah penelitian perbandingan antara bahasa Korea dan bahasa Indonesia. Tujuan penelitian ini adalah mendeskripsikan bentuk adverbia penanda waktu dalam bahasa Korea dan bahasa Indonesia dan menganalisis perbedaan dan persamaan dari adverbia penanda waktu bahasa Korea dan bahasa Indonesia. Peneliti membuat kalimat-kalimat sederhana dalam bahasa Korea dan menerjemahkannya ke dalam bahasa Indonesia sesuai dengan kaidah bahasa Indonesia yang berlaku sebagai objek analisis. Metode penelitian yang dipakai dalam penelitian ini adalah 대조언어학 (daejoeoneohak) atau dalam bahasa Indonesia disebut dengan metode perbandingan bahasa. Hasil penelitian menunjukan bahwa (1) bentuk adverbia penanda waktu dalam bahasa Korea dan bahasa Indonesia memiliki perbedaan yang sangat terlihat; (2) penanda waktu dalam bahasa Korea berupa adverbia tetapi dalam bahasa Indonesia bukan merupakan adverbia. Sebaliknya, dalam bahasa Indonesia yang menjadi penanda waktu adalah adverbia tetapi dalam bahasa Korea bukan berupa adverbia melainkan hanya partikel akhiran.

Kata kunci: adverbia, bahasa Indonesia, bahasa Korea, keterangan waktu, perbandingan bahasa 


\section{PENDAHULUAN}

Bahasa merupakan alat komunikasi sosial. Bahasa dibentuk dari berbagai macam unsur atau komponen-komponen yang tersusun secara teratur sesuai dengan pola tertentu dan membentuk suatu kesatuan. Bahasa dipakai dalam berbagai kegiatan mulai dari pendidikan, perdagangan, keagamaan, sampai hiburan. Dewasa ini, bahasa Korea menjadi salah satu bahasa asing yang banyak diminati oleh orang Indonesia seperti pelajar, mahasiswa atau siapa saja yang tertarik dengan negara Korea.

Minat orang-orang Indonesia untuk mempelajari bahasa Korea salah satunya disebabkan oleh masuknya Hallyu (gelombang budaya Korea) ke Indonesia. Budaya yang dimaksud tidak hanya yang berbau tradisional, tetapi juga yang berhubungan dengan budaya "kekinian" atau modern. Budaya Korea yang masuk ke Indonesia adalah budaya modern, seperti musik $K$ pop dan $K$-drama. Pengaruh budaya Korea yang sangat besar menimbulkan keinginan orang-orang untuk mempelajari bahasa Korea.

Bahasa Korea memiliki keunikan tersendiri jika dibandingkan dengan bahasa-bahasa lain. Aksara Korea bernama 'hangeul' menjadi pembeda yang paling dominan antara bahasa Korea dengan bahasa lainnya. Jika dibandingkan dengan bahasa Indonesia, bahasa Korea memiliki huruf vokal yang lebih banyak daripada bahasa Indonesia. Selain itu, susunan kata dalam kalimat juga berbeda. Jika dalam bahasa Indonesia kita mengenal struktur kalimat 'subjek + predikat + objek', tetapi struktur kalimat dalam bahasa Korea adalah 'subjek + objek + predikat'.

Dari pernyataan di atas terlihat bahwa posisi predikat yang terletak di akhir kalimat sangat berperan penting dalam struktur kalimat bahasa Korea. Pendengar tidak akan tahu maksud dari penutur jika kalimat belum selesai diucapkan atau dibacakan karena kata kerja atau predikat berada di akhir kalimat. Dalam bahasa Indonesia, istilah subjek, predikat, dan objek disebut dengan fungsi kalimat. Sedangkan dalam bahasa Korea disebut dengan 문장의 주요 성분 (munjange juyo seongbun) yang artinya komponen terpenting dalam kalimat.

Fungsi kalimat tentunya tidak hanya subjek, predikat, dan objek saja, tetapi ada juga kata keterangan atau biasa disebut dengan adverbia. Dalam bahasa Indonesia, kata keterangan dibagi menjadi beberapa jenis yaitu, kata keterangan waktu, kata keterangan tempat, kata keterangan cara dan lain sebagainya. Fungsi kata keterangan dalam bahasa Indonesia adalah untuk menandai kapan waktu kejadian terjadi, di mana kejadian itu terjadi, dan alat apa yang dipakai. Dalam bahasa Indonesia, kata keterangan ditandai dengan kata 'sudah', 'belum', 'nanti', 'akan' dan lain sebagainya. Sebagai salah satu dari kategori sintaksis utama, adverbia sering muncul dalam sebuah kalimat. Adverbia juga merupakan kata yang dipakai untuk memerikan verba, adjektiva, preposisi, atau adverbia lain, misalnya 'sangat', 'lebih', 'tidak' dan sebagainya (Kridalaksana, 2011: $3)$. 
Menurut Son (1996: 44-66), adverbia dalam bahasa Korea secara umum berfungsi sebagai pembatas bagi predikat dalam sebuah kalimat. Walaupun dalam bahasa Korea adverbia memiliki bentuk yang beragam, namun setiap adverbia tersebut memiliki karakteristik sintaksis dan semantik dalam mengekspresikan sebuah kalimat. Pada bahasa Korea, adverbia memiliki syarat khusus untuk bisa masuk ke dalam kalimat.

Salah satu adverbia yang sangat berperan penting dalam sebuah kalimat bahasa Korea maupun bahasa Indonesia adalah adverbia kewaktuan atau kata keterangan waktu. Adverbia kewaktuan adalah adverbia yang menggambarkan makna yang berhubungan dengan saat terjadinya peristiwa yang diterangkan oleh adverbia itu (Alwi, Lapoliwa dan Darmowidjojo, 2009: 202-206). Beberapa kata yang termasuk dalam adverbia tersebut adalah 'baru' dan 'segera'.

Kata keterangan waktu dalam bahasa Indonesia dapat berupa kata, frasa, atau anak kalimat. Hal ini sejalan dengan pendapat Keraf (1984: 72) bahwa keterangan waktu atau adverbia penanda waktu adalah suatu kata atau kelompok kata yang menduduki suatu fungsi tertentu, yaitu fungsi untuk menerangkan waktu atau kapan suatu peristiwa terjadi.

Dalam bahasa Korea, adverbia kewaktuan disebut 시간부사 (siganbusa). Adverbia waktu dalam bahasa Korea diklasifikasikan menjadi tiga waktu, yaitu waktu yang lampau 과거 (gwageo), waktu sekarang 현재 (hyeonjae), dan waktu yang akan datang 미래 (mirae). Kata keterangan waktu dalam bahasa Korea adalah semua kata keterangan yang memiliki fungsi mewakili waktu (Son, 1996: 35). Begitupun dengan bahasa Indonesia yang juga memiliki tiga keterangan waktu.

Dalam bahasa Korea, siganbusa dapat ditandai dengan dua hal, yaitu ditandai dengan 어휘 (eohwi) 'kosa kata' seperti 아까 (akka) 'tadi', 지금 (jigeum) 'sekarang', 나중에 (najunge) 'nanti' dan 조사 (josa) 'partikel' seperti ‘-었-, -는-, -겠-’. Sedangkan dalam bahasa Indonesia ditandai dengan kata keterangan waktu seperti 'sudah', 'sedang', 'akan', dan lain sebagainya. Bahkan kata lain selain adverbia, ada juga kelas kata lain yang dapat dijadikan penanda keterangan waktu seperti 'sekarang' dan 'tadi' yang keduanya merupakan kata benda.

Menurut Seo (2005), kata yang berhubungan dengan waktu digunakan untuk membatasi kalimat, klausa, atau frasa kata kerja. Park (2006) mengatakan bahwa siganbusa bukanlah kata keterangan, tetapi kata kerja yang menunjukkan kapan suatu peristiwa itu terjadi. Sebuah kalimat menjadi jelas maknanya saat kata yang berhubungan dengan waktu masuk di dalamnya.

Penelitian yang membandingkan adverbia waktu dalam bahasa Korea dan bahasa Indonesia belum ada. Akan tetapi, penelitian tentang perbandingan adverbia bahasa Indonesia dan bahasa asing lainnya sudah banyak dilakukan. Sinurat (2011) adalah salah satu yang meneliti tentang perbandingan antara kata keterangan waktu dalam bahasa Indonesia dan bahasa Man- 
darin. Sinurat menguraikan tentang adanya perbedaan dan persamaan penggunaan kata keterangan waktu antara bahasa Indonesia dan bahasa Mandarin. Penelitian Sinurat memaparkan bahwa kata keterangan bahasa Indonesia dan bahasa Mandarin memiliki kesamaan, yaitu sama-sama menggambarkan kejadian atau peristiwa yang terjadi di masa lampau, saat ini, dan masa yang akan datang. Akan tetapi, yang menjadi perbedaan utamanya adalah bentuk kata keterangan waktunya. Kata keterangan waktu bahasa Indonesia memiliki bentuk berbeda tetapi fungsi dan maknanya tetap sama jika ditulis dalam kalimat, seperti kata 'sudah' dan 'telah', 'sedang' dan 'tengah'. Sedangkan pada kalimat bahasa Mandarin, kata keterangan waktu memiliki bentuk yang berbeda dan fungsinya juga berbeda dalam kalimat.

Penelitian tentang adverbia penanda waktu juga diteliti dalam bahasa Jepang. Takefumi (2015) meneliti tentang kesalahan penggunaan adverbia penunjuk waktu 'ima' dan 'kyou' pada pemelajar bahasa Jepang di Indonesia. Takefumi mengatakan bahwa kata 'ima' dan 'kyou' memiliki makna 'sekarang' dalam bahasa Indonesia. Namun, kesalahan penggunaan kedua kata ini masih terjadi. Dalam bahasa Indonesia kata 'sekarang' terdapat beberapa makna yang tidak bisa dipergunakan atau dialihbahasakan begitu saja ke dalam bahasa Jepang, sehingga pemelajar bahasa Jepang perlu diberikan pengetahuan tentang penggunaan kata 'ima' dan 'kyou'.

Penelitian lainnya tentang penanda waktu dalam bahasa Jepang juga dilakukan oleh Fauziah (2017). Penelitian ini mendeskripsikan struktur dan makna adverbia penanda waktu 'mou sugu', 'mamonaku', dan 'sorosoro' dalam kalimat bahasa Jepang serta mendeskripsikan relasi makna ketiga adverbia tersebut. Penelitian ini memiliki kesimpulan bahwa kata 'mou sugu' memiliki makna 'segera' atau 'tak lama lagi' dalam bahasa Indonesia. Kata 'mou sugu' digunakan untuk menerangkan sesuatu hal yang terjadi atau dilakukan setelah waktu yang pendek, jangka waktu tersebut dalam hitungan menit atau hari. Kata 'mamonaku' memiliki makna 'segera', 'sedikit lagi', 'dalam waktu dekat' dalam bahasa Indonesia. Tetapi berbeda dengan kata 'mou sugu', 'mamonaku' digunakan untuk menunjukkan waktu pada sesuatu hal atau akan terjadi sebuah kondisi dalam waktu yang pendek, biasanya berupa suatu jadwal atau waktu dengan fakta yang tidak semua orang tahu (objektif). Kata 'sorosoro' memiliki makna 'tak lama lagi', 'sudah waktunya', 'perlahan-lahan' dalam bahasa Indonesia. Kata ini menunjukkan waktu untuk sesuatu hal atau segera terjadi sebuah kondisi dalam waktu yang pendek (subjektif atau objektif).

Dari penelitian-penelitian di atas terlihat bahwa adverbia penanda waktu dalam bahasa asing lainnya harus diterjemahkan ke dalam bahasa Indonesia secara hati-hati. Tidak semua adverbia penanda waktu dalam bahasa asing, khususnya dalam penelitian-penelitian di atas, memiliki padanan kata dalam bahasa Indonesia yang bentuknya juga sama yaitu adverbia. 
Maka dari itu, peneliti merasa penting untuk memberi gambaran bagaimana bentuk dan analisis adverbia penanda waktu dalam bahasa Korea dan bagaimana jika adverbia penanda waktu tersebut diekspresikan ke dalam bahasa Indonesia. Melalui penelitian ini, peneliti membahas beberapa adverbia penanda waktu dalam bahasa Korea yang mewakili penanda waktu lampau, sekarang, dan yang belum terjadi.

\section{METODE PENELITIAN}

Penelitian ini merupakan penelitian kualitatif dengan menggunakan metode penelitian bahasa Korea yang disebut 대조언어학 (daejoeoneohak) atau dalam bahasa Indonesia disebut dengan metode perbandingan bahasa. Perbandingan bahasa merupakan penelitian yang dilakukan dengan cara membandingkan dua atau lebih bahasa yang berbeda. Dalam analisisnya, kedua bahasa tersebut harus kontras dan memiliki kekhasannya masing-masing. Metode ini juga melibatkan dua atau lebih bahasa dengan menganalisis kesamaan dan perbedaan antara struktur formal bahasa (Kim, 2006).

Pada penelitian ini, metode penelitian perbandingan bahasa digunakan untuk menerangkan, menggambarkan, dan membandingkan kata keterangan waktu atau adverbia waktu pada bahasa Korea dan bahasa Indonesia. Tujuan digunakannya metode ini adalah untuk membantu pembelajar bahasa Korea untuk mempelajari bahasa Korea dengan lebih mudah. Sa lah satunya adalah dengan menggambarkan perbedaan adverbia waktu bahasa Korea dan bahasa Indonesia.

Penelitian ini menggunakan kalimat-kalimat sederhana yang dibuat oleh peneliti sebagai objek kajian. Kalimatkalimat yang digunakan harus memenuhi syarat, yaitu terdapat adverbia waktu dalam kalimatnya. Kalimat ditulis menggunakan bahasa Korea dan diterjemahkan ke dalam bahasa Indonesia sesuai dengan kaidah bahasa Indonesia yang berlaku. Lalu kalimat dalam bahasa Korea dan bahasa Indonesia dibandingkan dan dideskripsikan sesuai dengan kasus yang ditemukan.

\section{HASIL DAN PEMBAHASAN}

Alwi, dkk. (2009: mengungkapkan bahwa adverbia kewaktuan adalah kata yang menggambarkan makna yang berhubungan dengan saat terjadinya peristiwa yang diterangkan oleh adverbia itu. Sedangkan Seo (2005:15) mengatakan bahwa adverbia waktu termasuk kata keterangan yang bebas dan tidak memiliki pengaruh pada makna kalimat jika dihilangkan.

Dari dua definisi di atas, peneliti membandingkan adverbia waktu bahasa Korea dan bahasa Indonesia. Terdapat tiga klasifikasi waktu dalam bahasa Korea dan bahasa Indonesia, yaitu waktu yang lampau 과거 (gwageo), waktu sekarang 현재 (hyeonjae), dan waktu yang akan datang 미래 (mirae). 
Perbandingan kata keterangan waktu bahasa Korea dan bahasa Indonesia 시간부사 비교 (siganbusa bikyo) Dalam bahasa Korea, keterangan waktu bisa diekspresikan dengan menggunakan kosa kata 어휘 (eohwi) atau akhiran penutup kalimat penanda waktu 종결 어미 (jonggyeol eomi). Hal ini terdapat pada contoh kalimat berikut :

\section{(1) a. 아버지는 방금/아까 회사에 갔다. abeoji-neun banggeum/akka hwe- sa-e gatda \\ Ayah tadi sudah pergi ke kantor. \\ b. 아버지는 방금/아까 회사에 갔다. Abeoji-neun banggeum/akka hwesa-e gatda \\ Ayah tadi pergi ke kantor.}

Pada kalimat (1) terdapat dua kalimat yang sama dalam bahasa Korea yang menggambarkan kejadian waktu yang sudah lampau 과거 (gwageo). Pada kedua kalimat terdapat adverbia 방금/아까 (banggeum/akka) yang jika diterjemahkan dalam bahasa Indonesia memiliki arti 'tadi', 'barusan', atau 'baru saja'. Jika dilihat pada kalimat (1a) 'abeoji-neun banggeum/akka hwesa-e gatda.' dalam bahasa Indonesia kata keterangan waktu diekspresikan menjadi kata 'tadi sudah'. Kata 'banggeum/akka' diekspresikan menjadi kata 'tadi' dalam bahasa Indonesia. Kata 'sudah' digunakan untuk menggambarkan partikel '-었-' sebagai penanda waktu lampau dalam bahasa Korea.

Akan tetapi, dalam bahasa Indonesia, kata 'tadi' bukan termasuk ke dalam adverbia, tetapi merupakan kata benda (noun) yang memiliki makna waktu yang belum lama berlalu. Pada kalimat (1a) terdapat kata 'sudah' yang digunakan untuk menggambarkan partikel '었-' yang dalam bahasa Korea bukan merupakan adverbia, melainkan 선어말 어미 (seoneomal eomi) 'akhiran yang diletakkan pada predikat di depan akhiran terakhir untuk memperlihatkan penghormatan atau keterangan', sedangkan dalam bahasa Indonesia kata 'sudah' merupakan adverbia.

Kata 'sudah' sebagai adverbia bisa digantikan perannya oleh kata 'tadi' yang merupakan kata benda dan dapat dianggap sebagai penanda keterangan waktu lampau, sehingga kata 'sudah' dapat dihilangkan. Akan tetapi jika dilihat dalam kalimat bahasa Korea, kata 'banggeum/akka' masih harus didampingi dengan kata '갔다' (gatda) yang berarti 'sudah pergi'. Kata 'gatda' berasal dari kata dasar '가다' ( gada) yang memiliki arti 'pergi' ditambah dengan partikel '-었-' sebagai penanda waktu lampau. Jadi, dalam bahasa Korea walaupun dalam satu kalimat sudah menggunakan adverbia sebagai penanda waktu lampau, pertikel penanda waktu lampau '-었-' harus tetap digunakan dalam predikat dan tidak bisa dihilangkan.

(2) a. 그는 지금/이제 공부하고 있다. geu-neun jigeum/ije gongbu-hago itda

Dia sekarang sedang belajar.

b. 동생은 공부를 하다가 지금/이제 텔레비전을 보고 있다. dongsaeng-eun gongbu-reul hadaga jigeum/ije thellebijeon-eul 
bo-go itda

Setelah adik belajar, sekarang dia sedang menonton televisi.

Kalimat (2) merupakan kalimat yang menyatakan waktu sekarang 현재 (hyeonjae) yang ditandai dengan adverbia penanda waktu sekarang '지금/이제' (jigeum/ije) dan dalam bahasa Indonesia dapat diekspresikan menggunakan kata 'sekarang'. Pada kalimat (2a) dalam bahasa Korea dan bahasa Indonesia terdapat dua penanda keterangan waktu sekarang yaitu, dalam bahasa Korea kata 'jigeum/ije' dan akhiran '-고 있다' (go-itda) yang memiliki makna 'sedang'. Kata 'jigeum/ije' merupakan adverbia dalam bahasa Korea sedangkan '-고 있다' (go-itda) bukan merupakan adverbia, melainkan akhiran yang melekat pada predikat yang menyatakan bahwa kejadian tersebut sedang berlangsung. Sama seperti sebelumnya, meskipun sudah terdapat adverbia dalam kalimat bahasa Korea, akhiran yang menunjukkan waktu pun harus dihadirkan.

Kalimat (2a) pada kalimat bahasa Indonesia juga memiliki dua penanda waktu sekarang yaitu kata 'sekarang' dan 'sedang'. Jika kita melihat kalimat 'Dia sekarang sedang belajar.', kata 'sekarang' dan 'sedang' saling mengisi satu sama lainnya. Kata 'sekarang' bukan merupakan adverbia, melainkan kata benda (noun) dan kata 'sedang'-lah yang merupakan adverbia. Akan tetapi, jika dilihat secara fungsi, kalimat kata 'sekarang' menempati fungsi kata keterangan, sedangkan frasa 'sedang belajar' menempati fungsi predikat. Jika salah satu dihilangkan, misalnya kata 'sekarang', maka kata 'sedang'lah yang menjadi adverbial.

Kalimat (2b) merupakan kalimat majemuk dengan dua predikat yang berbeda. Kalimat tersebut juga memiliki tiga penanda waktu. Pada kalimat 'dongsaengeun gongbu-reul ha-daga jigeum/ije thellebijeon-eul bo-go itda' terdapat akhiran '다가' (-daga) yang memiliki makna 'setelah' yang berarti aktivitas yang sudah selesai dilakukan. Lalu terdapat adverbia 'jigeum/ije' yang berarti kejadian waktu sekarang dan akhiran '-고 있다' (go-itda) yang menunjukan aktivitas yang sedang dilakukan.

Sedangkan dalam kalimat bahasa Indonesia 'Setelah adik belajar, sekarang dia sedang menonton televisi.' juga terdapat tiga penanda waktu yaitu kata 'setelah', 'sekarang', dan 'sedang'. Kata 'setelah' merupakan adverbia penanda waktu lampau. Pada kalimat (2a), adik telah menyelesaikan aktivitas belajarnya, lalu dilanjutkan dengan aktivitas lainnya dengan dihubungkan dengan kata 'sekarang' dan frasa 'sedang menonton' merupakan aktivitas yang sedang dilakukan.

a. 미나가 아직 잔다. mina-ga ajik janda Mina masih tidur.

b. 미나가 아직 안 잔다. mina-ga ajik an janda Mina belum tidur.

c. 동생이 밥을 아직 안 먹었다. 
dongsaeng-I bab-eul ajik an mogotda

Adik masih belum makan nasi.

Pada pola (3) terdapat tiga kalimat yang masing-masing memiliki penanda waktu (adverbia) yang sama dalam bahasa Korea tetapi jika diekspresikan ke dalam bahasa Indonesia menjadi berbeda. Kalimat (3a) '미나가 아직 잔다.' (mina-ga ajik janda) memiliki adverbia '아직' (ajik) yang dalam bahasa Indonesia dapat diartikan sebagai kata 'masih'. Kalimat 'Mina masih tidur.' memiliki makna bahwa kegiatan atau aktivitas Mina (tidur) masih atau sedang berlangsung. Sedangkan kalimat (3b) juga memiliki adverbia bahasa Korea yang sama '아직' (ajik) tetapi memiliki makna yang berbeda. Kalimat '미나가 아직 안 잔다.' ( $m i$ na-ga ajik an janda) memiliki makna 'Mina belum tidur'. Jika sebelumnya kata '아직' (ajik) dimaknai dengan kata 'masih', pada kalimat ini diterjemahkan ke dalam bahasa Indonesia dengan makna 'belum' karena pada kalimat bahasa Korea setelah adverbia '아직' (ajik) terdapat predikat negatif '안 잔다' (an janda). Menurut tata bahasa Korea, jika predikat setelah adverbia '아직' (ajik) bersifat negatif, maka kata kerja atau aktivitasnya belum dilakukan.

Berbeda dengan kalimat (3c) yang kedua makna 'masih' dan 'belum' dapat digabungkan. Kalimat '동생이 밥을 아직 안 먹었다.' (dongsaeng-I bab-eul ajik an mogotda) juga memakai adverbia '아직' (ajik) sebagai penanda keterangan waktu. Kalimat (3c) jika diubah ke dalam bahasa Indonesia maka akan menghasilkan kalimat
'Adik masih belum makan nasi'. Jika dijabarkan dengan lebih rinci, maka kata '아직' (ajik) merupakan adverbia penanda waktu dan diikuti dengan predikat '안 먹었다' (an mog-otda) yang memiliki makna tidak makan untuk beberapa waktu yang lama. Akhiran '-었-' sebagai penanda waktu lampau pada kalimat ini memiliki makna waktu makan yang sudah lewat. Jadi, karena ada kata '아직' (ajik) maka kalimat tersebut menjadi bermakna 'adik masih belum juga makan padahal waktu makan sudah lewat'.

\section{KESIMPULAN}

Penelitian di atas menunjukkan bahwa adverbia penanda waktu dalam bahasa Korea dan bahasa Indonesia berbeda bentuknya. Dalam bahasa Korea, kata 'banggeum/akka', 'jigeum/ije', dan 'ajik' termasuk ke dalam adverbia penanda waktu. Sementara jika diterjemahkan ke dalam bahasa Indonesia, kata-kata tersebut belum tentu berbentuk adverbia. Ekspresi keterangan waktu dalam bahasa Indonesia dapat berbentuk kelas kata lain, seperti nomina. Seperti kata 'banggeum/akka' merupakan kata penanda waktu lampau (gwageo) yang jika diterjemahkan ke dalam bahasa Indonesia menjadi kata 'tadi'. Kata 'tadi' dalam bahasa Indonesia termasuk ke dalam kata benda (nomina), bukan adverbia. Adapun padanan kata 'tadi' yaitu kata 'barusan' yang merupakan adverbia tetapi merupakan kata yang tidak baku.

Kata 'jigeum/ije' juga merupakan sigan busa atau adverbia penanda waktu dalam bahasa Korea. Kata 'jigeum/ije' 
merupakan adverbia penanda waktu sekarang (hyeonjae) yang jika diterjemahkan ke dalam bahasa Indonesia menjadi kata 'sekarang'. Sama seperti kata 'tadi', kata 'sekarang' juga merupakan kata benda (nomina), bukan adverbia.

Terakhir adalah kata 'ajik' yang merupakan adverbia penanda waktu kejadian yang belum terjadi (mirae). Dalam bahasa Indonesia, kata 'ajik' diekspresikan dengan kata 'masih'. Berbeda dengan kedua kata sebelumnya yang merupakan nomina, kata 'masih' merupakan adverbia penanda waktu.

Dari penelitian ini, kita juga bisa membandingkan bentuk keterangan waktu lain dari bahasa Korea, yaitu keterangan waktu yang dibentuk dari akhiran kalimat (eomi). Eomi dalam bahasa Korea bisa jadi penanda waktu lampau, sekarang, dan penanda kejadian yang belum terjadi seperti akhiran -었/았-, -고 있다, dan -ㄹ 것이다. Akhiran -었/았- dalam bahasa Indonesia menjadi kata 'sudah'. Kata 'sudah' merupakan adverbia penanda waktu dalam bahasa Indonesia. Lalu, akhiran -고 있다 dalam bahasa Indonesia menjadi kata 'sedang'. Sama seperti kata 'sudah', kata 'sedang' juga merupakan adverbia penanda waktu dalam bahasa Indonesia. Sedangkan akhiran -ㄹ 것이다 menjadi kata 'akan' jika diekspresikan ke dalam bahasa Indonesia. Kata 'akan' merupakan adverbia penanda waktu sama dengan kata 'sudah' dan 'sekarang'.

Dari penjelasan di atas, dapat diketahui bahwa adverbia penanda waktu dalam bahasa Korea jika diterjemahkan ke dalam bahasa Indonesia belum tentu bentuknya adverbia. Sedangkan akhiran penanda waktu dalam bahasa Korea (sigan eomi) jika diterjemahkan ke dalam bahasa Indonesia, semua bentuknya adalah adverbia.

Penelitian ini masih banyak kekurangan. Baik dari segi teori maupun dari segi data. Masih banyak adverbia penanda waktu atau adverbia secara keselurahan dalam bahasa Korea yang bisa diteliti. Keberagaman penelitian tentang adverbia akan menjadi sumber yang penting untuk pemelajaran bahasa Korea di Indonesia. Para pemelajar bahasa Korea di Indonesia tidak akan kesulitan dalam memahami adverbia bahasa Korea yang fungsinya sangat penting dalam kalimat.

Peneliti berharap, pemelajar dan pengajar bahasa, khususnya bahasa Korea, tidak hanya sekedar mengetahui dan mengajarkan kosa kata dan tata bahasa saja, tetapi juga memahami fungsi dan makna sebuah kata dalam kalimat. Adverbia waktu menjadi salah satu yang penting untuk diketahui oleh pemelajar dan pengajar bahasa Korea. Hal ini dikarenakan dengan adanya adverbia dalam sebuah kalimat, kita lebih mengetahui situasi yang ada dalam kalimat walaupun pemberi pesan hanya memberikannya dalam bentuk tulisan.

Penelitian ini juga diharapkan dapat memberi manfaat bagi para pemelajar dan pengajar bahasa Korea di Indonesia, sebagai salah satu referensi bagi penelitian selanjutnya, khususnya di bidang studi perbandingan bahasa Korea dan bahasa Indonesia. Penelitian selanjutnya diharap- 
kan dapat menyempurnakan kekurangan yang ada di penelitian ini.

\section{DAFTAR PUSTAKA}

Alwi, H., Lapoliwa, H., Darmowidjojo, S. (2009). Tata Bahasa Baku Bahasa Indonesia. Balai Pustaka.

Fauziah, R. W. (2017). Adverbia "Mousugu”, "Mamonaku”, dan "Sorosoro" yang Memiliki Makna 'Tak Lama Lagi' dalam Kalimat Bahasa Jepang. Universitas Diponegoro.

Keraf, G. (1984). Tata Bahasa Indonesia. Nusa Indah.

Kim, C. S. (2006). Current Status and Prospect of Korean Literature Education in Korean Education. Bikyomunhwa Yeongu, 18, 25-39. http://www.riss.kr/search/detail/Detail View.do?p_mat type $=1 \mathrm{a} 0202 \mathrm{e} 37 \mathrm{~d} 52 \mathrm{c}$ 72d\&control_no=8fcd0caee8021150ff e0bdc3ef48d419\&outLink=N

Kobayashi, T. (2017). Analisis Kesalahan Penggunaan Adverbia Penunjuk
Waktu "Ima” pada Mahasiswa Pembelajar Bahasa Jepang di Indonesia. Universitas Pendidikan Indonesia.

Kridalaksana, H. (2011). Kamus Linguistik. Ikrar Mandiri Abadi.

Park, D. Y. (2006). A Study on the Aspect of Activity and Accomplishment Verbs in Modern Korea. Hangukhak Yeongu, Vol. 15, 231-251.

http://www.koling.org/modules/doc/i ndex.php?doc=intro

Sinurat, H. (2011). Analisis Kontrastif Kata Keterangan Waktu dalam Bahasa Indonesia dan Bahasa Mandarin. Universitas Sumatera Utara.

Son, N. I. (1996). Gukgeeo busa-wa susik daesang: Korean adverbs and formula targets. Hangugeo-hak, Vol. 4, 4766.

https://www.hanmalgeul.org/m/475

Seo, S. J. (2005). Hangugeo-eui busa: Korean Adverb. Seoul National University Press. 